\title{
Institutional Plan
}

\section{FY 2002-2006}

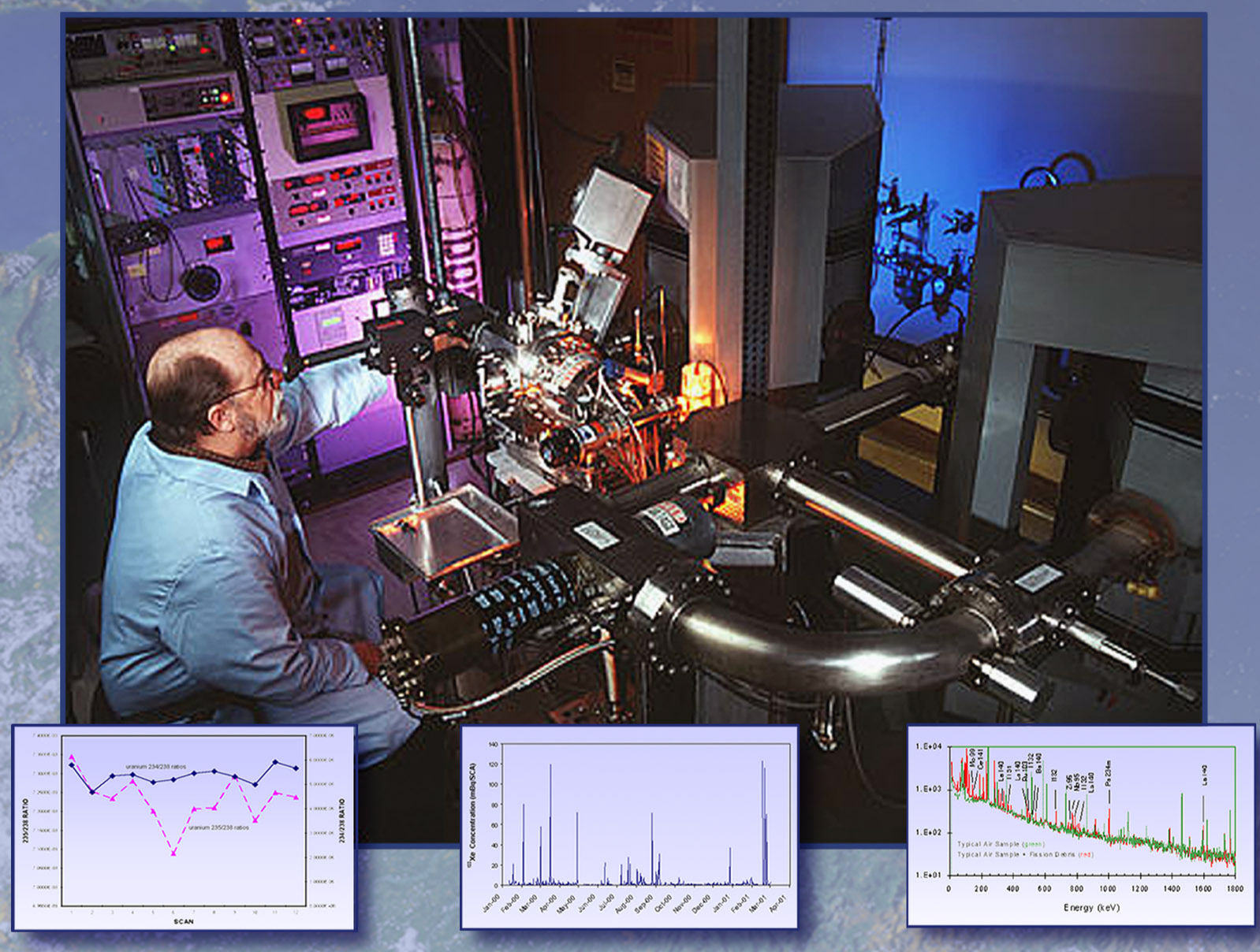

Pacific Northwest National Laboratory

Operated by Battelle for the U.S. Department of Energy 


\section{Science to Solutions}

At Pacific Northwest National Laboratory, science and technology enable advanced solutions for the most difficult challenges we face in protecting our country against threats to national security. Never before in the history of the United States has it been more important to monitor the activity of rogue nations and terrorist groups. Advanced science and technology give our nation key tactical advantages in monitoring, detecting, gathering information, and maintaining the deterrent against weapons of mass destruction.

\section{Critical Challenges and Timely Opportunities}

Potential adversaries can employ new technology, concealment, and deception to thwart our defenses and take advantage of our open society. Meeting these challenges requires the best and brightest scientific talent, new ideas, and demonstrated ability to deliver effective solutions. Our national security programs are backed by strong technical capabilities in several key scientific areas.

\section{Monitoring the Threat}

Pacific Northwest National Laboratory has developed treaty monitoring instruments that reduce the global danger from weapons of mass destruction, enhance international nuclear safeguards, promote nuclear nonproliferation, and help eliminate inventories of surplus nuclear weapons materials.
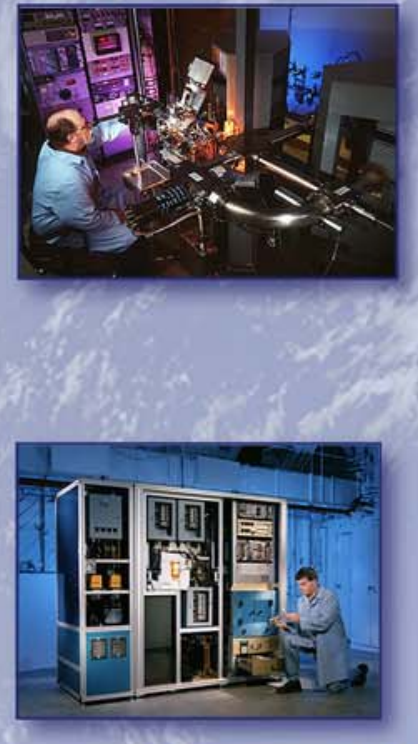

Our cover photograph highlights an exceptionally sensitive thermal ionization mass spectrometer that we use to measure the isotopic content of special environmental samples from worldwide monitoring.

Changes in isotopic ratios, measured by the thermal ionization mass spectrometer, provide essential information about the ongoing production and testing of nuclear devices.

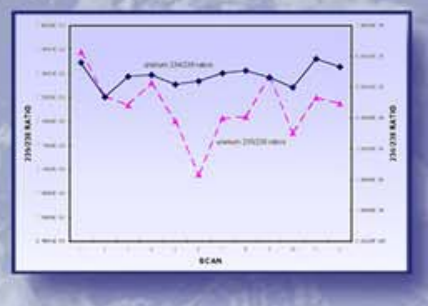

To an extent never before possible, we can pinpoint the locations of nuclear testing using two devices developed at Pacific Northwest National Laboratory. The Automated Radioxenon Sampler Analyzer and the Radionuclide Aerosol Sampler/Analyzer are being deployed worldwide to verify international compliance with nuclear treaties. These two breakthrough technologies permit fast, accurate, and economical detection of radionuclides emitted from nuclear detonations. The Automated Radioxenon Sampler Analyzer is about 100 times more sensitive than other common measurement systems for detecting fission products from underground nuclear testing. These instruments will be located around the world to monitor proliferation of nuclear weapons.

Background measurements of ${ }^{133} \mathrm{Xe}, 131 \mathrm{mXe}, 133 \mathrm{~m} \mathrm{Xe}$, and ${ }^{135} \mathrm{Xe}$ discriminate normal commercial reactor operations from underground nuclear weapons detonations. We have developed the first instrument capable of measuring all of the xenon isotopes with high sensitivity.

Air samples provide strong evidence of tests conducted in or leaking into the atmosphere. Any one of the small red peaks in this radioisotope spectrum would individually constitute a confident detection. Taken together, they form incontrovertible proof of testing.
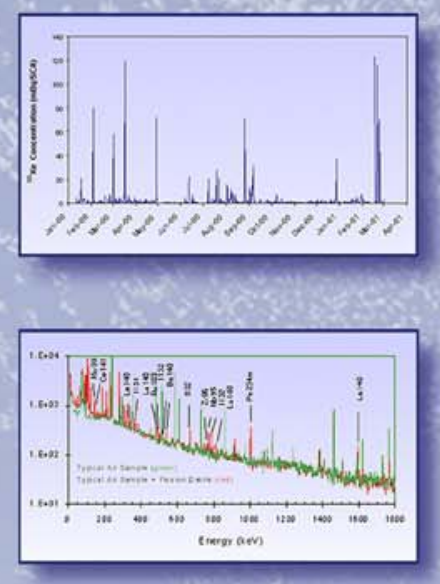


\title{
DISCLAIMER
}

This report was prepared as an account of work sponsored by an agency of the United States Government. Neither the United States Government nor any agency thereof, nor Battelle Memorial Institute, nor any of their employees, makes any warranty, express or implied, or assumes any legal liability or responsibility for the accuracy, completeness, or usefulness of any information, apparatus, product, or process disclosed, or represents that its use would not infringe privately owned rights. Reference herein to any specific commercial product, process, or service by trade name, trademark, manufacturer, or otherwise does not necessarily constitute or imply its endorsement, recommendation, or favoring by the United States Government or any agency thereof, or Battelle Memorial Institute. The views and opinions of authors expressed herein do not necessarily state or reflect those of the United States Government or any agency thereof.

\author{
PACIFIC NORTHWEST NATIONAL LABORATORY \\ operated by \\ BATTELLE \\ for the \\ UNITED STATES DEPARTMENT OF ENERGY \\ under Contract DE-AC06-76RL01830
}

Printed in the United States of America

Available to DOE and DOE contractors from the

Office of Scientific and Technical Information, P.O. Box 62, Oak Ridge, TN 37831; prices available from (615) 576-8401.

Available to the public from the National Technical Information Service, U.S. Department of Commerce, 5285 Port Royal Rd., Springfield, VA 22161

PNNL-13750

This document was printed on recycled paper. 


\title{
Pacific Northwest National Laboratory Institutional Plan FY 2002-2006
}

\author{
D. R. Fisher \\ E. W. Pearson
}

January 2002

\author{
Prepared for the \\ U.S. Department of Energy \\ under Contract \\ DE-AC06-76RL01830
}

Pacific Northwest National Laboratory

Richland, Washington 99352 


\section{Contents}

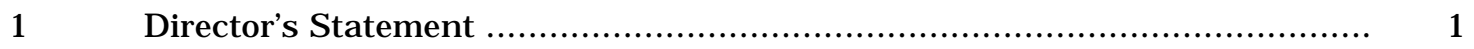

2 Laboratory Mission, Roles, and Technical Capabilities ................................ 4

Mission and Roles ................................................................... 4

Technical Capabilities ................................................................. 5

$3 \quad$ Laboratory Strategic Plan .............................................................. 8

Key Planning Assumptions ....................................................... 9

Strategic Conclusions ................................................................... 12

Achieving Our Vision: Priorities and Actions ................................... 13

Enhancing Our Roles in DOE's Missions ...................................... 14

Laboratory Agenda ................................................................... 16

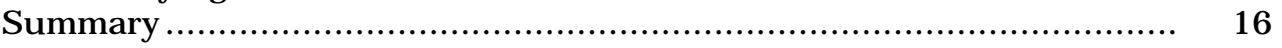

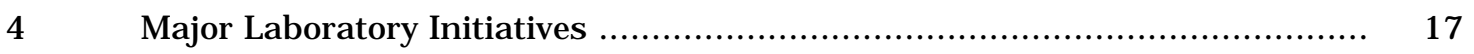

Biomolecular Networks .............................................................. 18

Computational Sciences and Engineering........................................ 24

Nanoscience and Nanotechnology ............................................... 29

Bio-Based Products ................................................................... 32

Carbon Management ....................................................................... 33

Fuel Cell Technology ........................................................... 36

Imaging Science and Technology ….......................................... 39

Infrared Sensing ...................................................................... 41

Advanced Nuclear Science and Technology ...................................... 44

Energy Systems Transformation ...................................................... 46

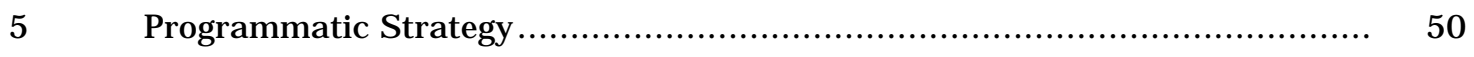

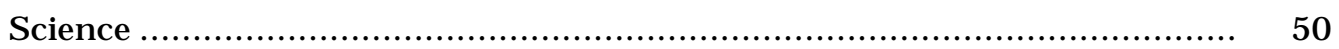

Strategic Intent ..................................................................... 50

Our Role in Supporting the Themes and Challenges of DOE Science ....... 51

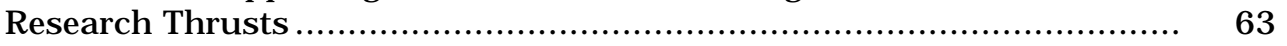

Environmental Guality ................................................................ 67

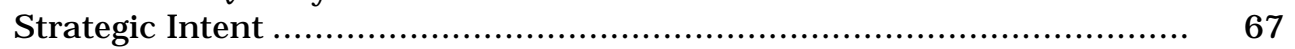

Capability Development: Role of Laboratory Initiatives ....................... 76

Major Research and Development Thrusts .................................... 76

National Security ................................................................ 78

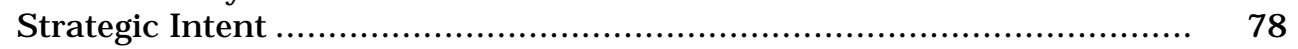

Our Role in the National Security Research and Development Portfolio ... 80

Major Research and Development Thrusts ....................................... 87

Capability Development: Role of Laboratory Initiatives ....................... 88

Energy Resources .................................................................. 89

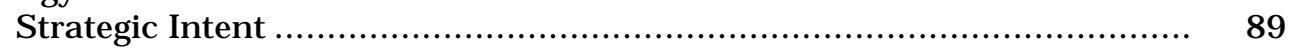

Our Role in the Energy Resources Research and Development Portfolio... 90

Major Research and Development Thrusts ..................................... 93

Capability Development: Role of Laboratory Initiatives ........................ 94 
$6 \quad$ Operations and Infrastructure Strategic Plan ................................. 96

Performance-Based Management ................................................. 96

Human Resources .................................................................... 99

Environment, Safety, and Health Management .............................. 102

Security, Safeguards, and Nonproliferation .................................. 106

Site and Facilities Management ................................................. 110

Information Resources ........................................................ 119

Communications and Trust f.............................................. 122

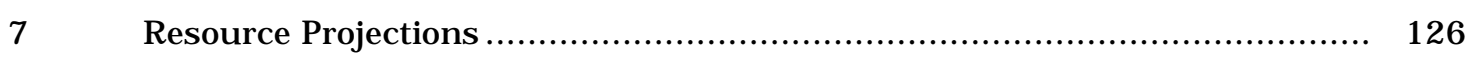

Subcontracting and Procurement ............................................. 136

Small and Disadvantaged Business Procurement ............................. 136

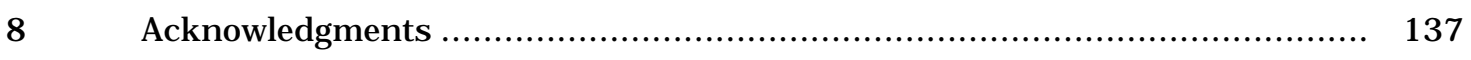

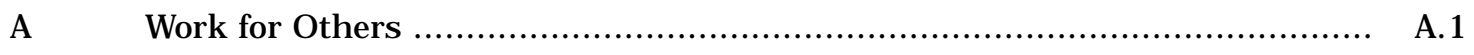

B University and Industrial Partnerships and Collaborations ........................ B. 1

C Laboratory Directed Research and Development.................................... C. 1 